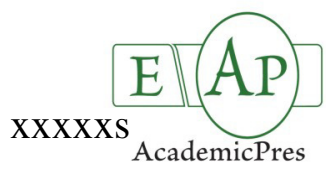

\title{
Effect of Supplemental Irrigation on Lentil Yield and Growth in Semi-Arid Environment
}

\author{
Abdullah KAHRAMAN ${ }^{1 *}$, Mohd. Kamran $\mathrm{KHAN}^{1}$, Anamika PANDEY ${ }^{1}$, \\ Ergun DOGAN ${ }^{2}$
}

\author{
${ }^{1}$ Harran University, Faculty of Agriculture, Department of Field Crops, Sanliurfa 63040, \\ Turkey;kahraman@harran.edu.tr ("correspondingauthor);mohdkamran.biotech@gmail.com;anamikabiotech@gmail.com \\ 2InonuUniversity, Faculty of Agricultural Engineering,Department of Horticultural Crops, Malatya 44300,Tunkey; ergun.dogan@inonu.edu.tr
}

\begin{abstract}
Lentil is one of the most promising legume crops providing nutritional and food assurance to human beings. Due to extensive production of lentil crop in rain-fed agriculture system, its growth and yield are mainly determined by the levels of precipitation. Consequently, it usually faces drought stress during the generative stage resulting in low yield. In such scenario, controlled supplemental irrigation (SI) can improve and stabilize the productivity. Therefore, the present study was conducted to determine the effect of supplemental irrigation on the growth and yield of lentil crop under semi-arid climate conditions of Turkey. An experiment was performed during two consecutive crop seasons at Sanliurfa, Turkey with annual mean rainfall of 196 and $275 \mathrm{~mm}$ in the first and second experimental year, respectively. Six supplementary irrigation treatments were given using drip irrigation system [no supplement irrigation $\left(\mathrm{I}_{0}\right), 25 \%\left(\mathrm{I}_{25}\right), 50 \%\left(\mathrm{I}_{50}\right), 75 \%\left(\mathrm{I}_{75}\right), 100 \%\left(\mathrm{I}_{100}\right.$, full irrigation) and $125 \%$ $\left(\mathrm{I}_{125}\right)$ supplement irrigation depending on the available soil water content]. Results obtained in the study indicated that in both study years, highest biomass, harvest index and grain yield values were obtained from fully irrigated treatments $\left(\mathrm{I}_{100}\right)$, while non-supplementary irrigated treatments have provided lowest values. It should be clearly noticed that growth parameters including yield were lower under over-irrigation treatment $\left(\mathrm{I}_{125}\right)$. Hence, it is recommended that farmers need to optimize the supplemental irrigation technique to obtain desired yields. This study will support the successful usage of the supplemental irrigation technology to improve lentil productivity, particularly under semi-arid environment.
\end{abstract}

Keywords: drought, lentil, rain-fed agriculture, supplemental irrigation, semi-arid climate, yield components

\section{Introduction}

Lentil (Lens culinaris Medik.) is one of the most important pulse crops of the world that is consumed for its high protein and mineral content. The crop including red, green and black types is an excellent source of dietary fibers and B-complex vitamins. In addition to human consumption, high-quality lentil hay is extensively used as animal feed (Lardy and Anderson, 2009). It also supports crop rotation due to its potential to sustain soil productivity by nitrogen fixation (Abi-Ghanem et al., 2011).

In 2015, the total world lentil production was around 4.9 million tons. Since more than last one decade, Turkey has been the third largest producer of lentils in the world, after Canada and India (FAOSTAT 2015). USDA GAIN report mentions that South-eastern part of Turkey contributes $75-80 \%$ of total red lentil production (Serttas, 2009; Sarker and Kumar, 2011). However, this region is characterized by dry summers and poses a challenge of terminal drought stress for the plants resulting farmers to plant the crop during autumn and harvest in early summer. In addition, intermittent drought stress occurs during the vegetative growth period and adversely affects the yield.

In last decade, farmers in the South-eastern Turkey has low lentil yields mainly due to elevated temperature and low precipitation. In such scenario, supplemental irrigation can be an efficient technique to cope with the limited water availability and to stabilize the crop yields (Oweis and Hachum, 2012). Supplemental irrigation is the partial supply of water to the crops, when soil moisture is low and during critical growth stages to increase the crop growth and water productivity (Oweis and Hachum, 2003).

A number of researchers have conducted studies to estimate the effects of supplemental irrigation on crop yields under different growth environments and at different growth stages (Saxena, 1981; Pala and Mazid, 1992; Hamdi et al., 1992; Silim et al., 1993; Zhang et al., 2000; Oweis et al., 2004; Shamsi et al., 2010; Baker et al., 2012; Erekul et al., 2012; Dogan et al., 2013; Girma and Haile, 2014; Sui et al., 2014; Soltani et al., 2015; Ali et 
238

al., 2015). Hamdi et al. (1992) indicated 20\% rise in seed yield per plant in two supplemental irrigations $(50 \mathrm{~mm}$ each) in Syrian growth conditions. Zhang et al. (2000) showed $70 \%$ increase in lentil grain yield on 1 or 2 applications of irrigation at flowering or pod-filling stage. Additionally, they emphasized on the effectiveness of supplemental irrigation in dry season in comparison to the wet season. Oweis and Hachum (2001) highlighted the effect of different sowing dates on supplemental irrigation requirement of wheat crop in Syria. They claimed that multi-sowing date method can reduce the supplemental irrigation water demand by more than $20 \%$, thereby decreasing the irrigation cost. After conducting a four years experiment, Oweis et al. (2004) found that supplemental irrigation (SI) increased the lentil grain and biomass yield by raising its values from $1.04 \mathrm{t} \mathrm{ha}^{-1}$ and $4.27 \mathrm{tha}^{-1}$ (under rain-fed conditions) to $1.81 \mathrm{t} \mathrm{ha}^{-1}$ and $6.2 \mathrm{tha}^{-1}$ (under full SI conditions) respectively. However, they employed one-third, two-third and full supplemental irrigation stages and revealed maximum water productivity at $2 / 3$ SI level. Although they indicated augmented lentil biomass production by early sowing, they determined highest grain yield was attained at normal sowing date. In 2010, Singh $e t$ al. conferred that supplemental irrigation is one of the efficient methods for increasing the water use efficiency in agricultural system complementing the insufficient rainfall. They emphasized on its effectiveness to combat with the drawbacks of drought stress.

Attia and Barsoum (2013) performed two field trials to determine the effect of supplementary irrigation and biofertilization on lentil yields in Egypt. They tested three irrigation treatments [without supplementary irrigation (rain-fed), a supplementary irrigation of $45 \mathrm{~mm}$ and two supplementary irrigations of $90 \mathrm{~mm}$ ] and recommended the addition of two supplementary irrigations $(90 \mathrm{~mm})$ for higher lentil yields.

In an article, Soltani $e t$ al. (2015) emphasized to upgrade the low productivity of rain-fed lentils in Iran using supplemental irrigation. They tested the significance of sowing dates and supplement irrigation at different growth stages on lentil yield. Their results showed higher grain yield and better water productivity at double irrigation treatment and single irrigation treatment at seedling stage, respectively.
Other than these studies on lentil, Pandey et al. (2013) established a novel approach to simulate supplemental irrigation and possible benefits of a rainwater harvesting system in rain-fed agricultural regions. Employing the approach, they estimated the soil moisture availability, crop yields in both irrigated and rain-fed environments and the impact of size of an on-farm reservoir (OFR) system.

In Turkey, South-eastern Integrated Development Project (SIDP) has targeted to utilize 1.2 million hectare land in Southeastern Turkey for irrigation farming. This will promote the lentil production as it is the second most extensively grown crop in the region. As information on the effect of supplementary irrigation on lentil yield in different regions of the world is limited; current study was performed to determine the effect of supplemental irrigation on crop growth parameters and the resulting lentil yield under the semi-arid climatic conditions of the South-eastern region of Turkey known as the Fertile Crescent.

\section{Materials and Methods}

\section{Experimental site and weather conditions}

The experiment was conducted during two consecutive crop seasons at Faculty of Agriculture, Harran University, Turkey. The study area had clay loam soil (Vertic Calciorthid Aridisol) with average field capacity of $31.9 \%$, permanent wilting point of $22.1 \%$, available water of $77.3 \mathrm{~mm}$ at $60 \mathrm{~cm}$, and infiltration rate of $13 \mathrm{~mm} \mathrm{~h}^{-1}$. The soil bulk density value was approx. $1.4 \mathrm{~g} \mathrm{~cm}^{-3}$ with a $\mathrm{pH}$ of 7.2. Soil organic matter was low ranging from 0.6 to 1.2 depending on the active rooting depth. Weather components for both the experimental years were obtained from Turkish State Meteorological Services. The annual temperature, relative humidity and solar radiation values for the first and second study year were $15^{\circ} \mathrm{C}, 52 \%, 454 \mathrm{cal} \mathrm{cm}^{-2}$ and $14^{\circ} \mathrm{C}, 55 \%$, and $440 \mathrm{cal} \mathrm{cm}^{-2}$, respectively (Table 1 ). The 'Firat- 87 ' lentil cultivar was used as the plant material because it is the one of most commonly grown cultivars in South-eastern Turkey. The active root depth was assumed to be $60 \mathrm{~cm}$ for irrigation purposes. The water used for irrigation had a $\mathrm{pH}$ of 7.00, an EC of $0.31 \mathrm{dS} \mathrm{m}^{-1}$, and a SAR of 0.25 and was categorized as $\mathrm{C}_{2} \mathrm{~S}_{1}$

Table 1. Weather data of the study area (Sanliurfa, Turkey) during both the experimental years

\begin{tabular}{|c|c|c|c|c|c|c|c|}
\hline \multicolumn{2}{|c|}{ Parameters / Months } & $\begin{array}{c}\text { Min. Air Temp. } \\
\left({ }^{\circ} \mathrm{C}\right)\end{array}$ & $\begin{array}{c}\text { Max. Air Temp. } \\
\left({ }^{\circ} \mathrm{C}\right)\end{array}$ & $\begin{array}{c}\text { Av. Temp. } \\
\left({ }^{\circ} \mathrm{C}\right)\end{array}$ & $\begin{array}{c}\text { Precipitation } \\
(\mathrm{mm})\end{array}$ & $\begin{array}{c}\text { Relative } \\
\text { Humidity (\%) }\end{array}$ & $\begin{array}{c}\text { Solar Radiation } \\
\left(\mathrm{Cal} \mathrm{cm}^{-2}\right)\end{array}$ \\
\hline \multirow{9}{*}{ 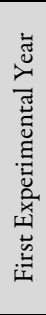 } & November & 2.2 & 26.8 & 12.5 & 15.4 & 58.1 & 252.0 \\
\hline & December & -2.0 & 16.1 & 6.8 & 45.6 & 65.5 & 195.1 \\
\hline & January & -3.2 & 13.5 & 3.7 & 57.1 & 52.2 & 230.1 \\
\hline & February & -3.1 & 17.5 & 6.6 & 28.3 & 59.9 & 316.4 \\
\hline & March & 4.2 & 29.5 & 14.7 & 12.4 & 55.7 & 503.3 \\
\hline & April & 6.0 & 36.4 & 20.4 & 1.8 & 48.0 & 608.1 \\
\hline & May & 9.9 & 37.0 & 22.1 & 26.7 & 47.2 & 726.0 \\
\hline & June & 17.8 & 42.3 & 29.8 & 8.6 & 29.8 & 797.7 \\
\hline & Average & 4.0 & 27.4 & 14.6 & 24.5 & 52.1 & 453.6 \\
\hline \multirow{9}{*}{ 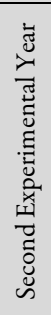 } & November & 6.0 & 24.7 & 14.0 & 35.3 & 62.3 & 255.4 \\
\hline & December & -1.7 & 19.5 & 7.0 & 37.7 & 58.6 & 199.3 \\
\hline & January & -4.7 & 15.7 & 5.7 & 29.8 & 59.1 & 213.9 \\
\hline & February & 0.1 & 17.3 & 8.0 & 54.5 & 72.2 & 253.9 \\
\hline & March & 1.5 & 23.0 & 10.0 & 55.3 & 65.6 & 460.1 \\
\hline & April & 5.9 & 27.5 & 15.8 & 48.8 & 53.0 & 627.2 \\
\hline & May & 10.0 & 37.0 & 22.7 & 4.7 & 36.3 & 755.8 \\
\hline & June & 17.8 & 40.0 & 29.6 & 9.2 & 29.1 & 754.7 \\
\hline & Average & 4.4 & 25.6 & 14.1 & 34.4 & 54.5 & 440.0 \\
\hline
\end{tabular}


(USSL, 1954).

In both the years, although the climatic conditions of the study area during the growth period were closer to long- term averages, first experimental year had higher temperature and solar radiation values with low humidity in comparison to the second year. In addition, considering the temperature and rainfall, the first year was drier than the second year. The rainfall amounts in first and second year were 196 and $275 \mathrm{~mm}$, respectively (Table $1)$.

\section{Experimental design and treatments}

The experimental area was twice cultivated prior to sowing. Size of the experimental plots was $6 \times 1.2 \mathrm{~m}$, consisting of six rows with $1.7 \mathrm{~cm}$ spacing within the rows and $20 \mathrm{~cm}$ distance between each row. In each trial plot, lentil seeds were sown to obtain a density of 300 seeds $\mathrm{m}^{-2}$ and $20 \mathrm{~kg} \mathrm{ha}^{-1}$ fertilizer containing pure nitrogen and phosphorus was supplied to each plot. In both the study years, seeds were sown and harvested in the month of November and May, respectively. Plants from the middle four rows of each plot were included in vegetative and generative measurements and the plants in the external rows plants were not involved in the study to avoid boundary effects.

Soil moisture of the experimental plots was gravimetrically measured twice a week and irrigations were accordingly scheduled. Initially, plots were fully irrigated ( $\mathrm{I}_{100}$ treatment) and further, supplementary irrigations were initiated after the soil water content reached $50 \%( \pm 5 \%)$ of the available water. Different supplementary irrigation treatments were given with a drip irrigation system depending on the percentage of the available soil water of the $\mathrm{I}_{100}$ treatment. Six treatments were $0 \%$ ( $\mathrm{I}_{0}$, dry land conditions), 25\% ( $\left.\mathrm{I}_{25}\right), 50 \%\left(\mathrm{I}_{50}\right), 75 \%\left(\mathrm{I}_{75}\right), 100 \%$ ( $\mathrm{I}_{100,}$, full irrigation) and $125 \%\left(\mathrm{I}_{125}\right)$ of the available soil water content. Each row of the trial plots had a drip irrigation lateral with a $41 \mathrm{~h} \mathrm{~h}^{-1}$ emitter flow rate and the drip lines had $20 \mathrm{~cm}$ emitter spacing. In both the years, immediately after sowing, 25 $\mathrm{mm}$ of irrigation water was applied to the trial plots to facilitate germination. Additionally, during the irrigation period in experimental years, three irrigations were performed that were started in April, and thereafter, soil water was measured periodically. Crop water use during the growing season was calculated using the water budget method (Doorenbos and Kassam, 1979).

$$
E T=I+P-D_{r}-R_{f} \pm \Delta s
$$

Here, ET is evapotranspiration (mm), I is irrigation water $(\mathrm{mm}), \mathrm{P}$ is the effective rainfall plus capillary rise $(\mathrm{mm}), \mathrm{D}_{\mathrm{r}}$ is drainage $(\mathrm{mm}), R_{f}$ is runoff $(\mathrm{mm})$, and $\Delta s$ is the change in the soil moisture content $(\mathrm{mm})$. In order to determine the water content, $30 \mathrm{~cm}$ layers were gravimetrically sampled to a depth of $90 \mathrm{~cm}$ prior to irrigation. As drip irrigation system was used and there were no excess irrigations or runoff during the irrigation seasons of either year, $R_{f}$ and $D_{r}$ were assumed to be zero, thus, reducing the equation to

$$
E T=I+P \pm \Delta s
$$

Again, here, ET is evapotranspiration ( $\mathrm{mm}$ ), I is irrigation water $(\mathrm{mm}), P$ is the effective rainfall plus capillary rise $(\mathrm{mm})$ and $\Delta s$ is the change in the soil moisture content $(\mathrm{mm})$.

The yield, biomass, plant height and 1000-seed weights of all the plants were determined, and the resulting harvest index $(\mathrm{HI})$, water use efficiency (WUE) and irrigation water use efficiency (IWUE, $\mathrm{kg} \mathrm{ha}^{-1} \mathrm{~mm}^{-1}$ ) were calculated. The water use efficiency (WUE, $\mathrm{kg} \mathrm{ha}^{-1} \mathrm{~mm}^{-1}$ ) and irrigation water use efficiency (IWUE) were calculated with the following equations (equations 3, 4, and 5), as outlined by Kanber (1999).

$$
\begin{aligned}
& H I=Y t / B M \\
& I W U E=(Y t-Y c) / I \\
& W U E=(Y t-Y c) / E T c
\end{aligned}
$$

Here, $\mathrm{Yt}$ is the yield value $\left(\mathrm{kg} \mathrm{ha}^{-1}\right), \mathrm{BM}$ is the biomass value $(\mathrm{kg}$ ha ${ }^{-1}$ ) of each trial plot, Yc is the yield value from the control treatment plot $\left(\mathrm{kg} \mathrm{ha}^{-1}\right), \mathrm{I}$ is the seasonal applied irrigation water $(\mathrm{mm}), \mathrm{ETc}$ is

\begin{tabular}{|c|c|c|c|c|c|c|c|}
\hline \multirow{2}{*}{ Parameters } & \multirow{2}{*}{ Year } & \multicolumn{6}{|c|}{ Irrigation Trials } \\
\hline & & $\mathrm{I}_{0}$ & $\mathrm{I}_{25}$ & $\mathrm{I}_{50}$ & $\mathrm{I}_{75}$ & $\mathrm{I}_{100}$ & $I_{125}$ \\
\hline \multirow{2}{*}{$\begin{array}{l}\text { Seasonal Irrigation Amount } \\
\text { (I. mm) }\end{array}$} & $1^{\text {st }}$ Year & 25 & 67 & 109 & 151 & 193 & 235 \\
\hline & $2^{\text {nd }}$ Year & 25 & 88 & 93 & 126 & 160 & 194 \\
\hline \multirow{2}{*}{$\begin{array}{l}\text { Seasonal Crop Water Use } \\
\text { (ETc. mm) }\end{array}$} & $1^{\text {st }}$ Year & 158 & 204 & 246 & 288 & 330 & 330 \\
\hline & $2^{\text {nd }}$ Year & 215 & 287 & 292 & 326 & 360 & 360 \\
\hline \multirow{2}{*}{ Plant Height $(\mathrm{cm})$} & $1^{\text {st }}$ Year & $14.3 \mathrm{a}$ & $25.0 \mathrm{~b}$ & $28.0_{\mathrm{c}}$ & $25.0 \mathrm{~b}$ & $33.7 \mathrm{~d}$ & $32.0_{\mathrm{d}}$ \\
\hline & $2^{\text {nd }}$ Year & $17.3_{\mathrm{a}}$ & $23.3 \mathrm{~b}$ & $24.3 \mathrm{~b}$ & $26.7 \mathrm{~b}$ & $30.7_{\mathrm{c}}$ & $32.7 \mathrm{c}$ \\
\hline \multirow{2}{*}{ Number of Branch } & $1^{\text {st }}$ Year & $3.0_{\mathrm{a}}$ & $5.7 \mathrm{~b}$ & $6.3 \mathrm{~b}$ & $6.0_{\mathrm{b}}$ & $7.0_{\mathrm{b}}$ & $6.3 \mathrm{~b}$ \\
\hline & $2^{\text {nd }}$ Year & $3.7 \mathrm{a}$ & $5.0_{\mathrm{ab}}$ & $5.7 \mathrm{~b}$ & $6.3 \mathrm{bc}$ & $8.0_{\mathrm{c}}$ & $7.3 \mathrm{c}$ \\
\hline \multirow{2}{*}{1000 seed weight $(\mathrm{g})$} & $1^{\text {st }}$ Year & $32.6 a$ & $35.5 a$ & $36.2 \mathrm{a}$ & $32.3 \mathrm{a}$ & $29.2_{a}$ & $31.3 a$ \\
\hline & $2^{\text {nd }}$ Year & $30.0_{\mathrm{a}}$ & $27.2 \mathrm{a}$ & $31.2_{\mathrm{a}}$ & $30.5 \mathrm{a}$ & $27.7 \mathrm{a}$ & $33.5 \mathrm{a}$ \\
\hline \multirow{2}{*}{ Biomass $\left(\mathrm{kg} \mathrm{ha}^{-1}\right)$} & $1^{\text {st }}$ Year & $2611_{a}$ & $4263 b$ & $4944 b$ & $5583 \mathrm{bc}$ & $6111_{d}$ & $5666_{c}$ \\
\hline & $2^{\text {nd }}$ Year & $3481_{a}$ & $4888_{b}$ & $5976_{c}$ & $65099_{c d}$ & $6912_{d}$ & $6033_{d}$ \\
\hline \multirow{2}{*}{ Yield $\left(\mathrm{kg} \mathrm{ha}^{-1}\right)$} & $1^{\text {st }}$ Year & $291_{a}$ & $415 \mathrm{~b}$ & $767_{c}$ & $1013 \mathrm{c}$ & $1536 \mathrm{~d}$ & $1403 \mathrm{~d}$ \\
\hline & $2^{\text {nd }}$ Year & $577 a$ & $1233 b$ & $1468 \mathrm{c}$ & $1566 \mathrm{c}$ & $1788_{d}$ & $1726 \mathrm{~d}$ \\
\hline \multirow{2}{*}{ Harvest Index } & $1^{\text {st }}$ Year & 0.06 & $0.10_{a}$ & $0.16_{b}$ & $0.18 \mathrm{~b}$ & $0.25 \mathrm{c}$ & $0.25 \mathrm{c}$ \\
\hline & $2^{\text {nd }}$ Year & $0.17 \mathrm{a}$ & $0.25 b$ & $0.25 b$ & $0.24 \mathrm{~b}$ & $0.26 \mathrm{~b}$ & $0.29 \mathrm{~b}$ \\
\hline \multirow{2}{*}{ 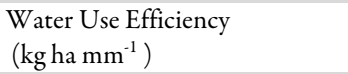 } & $1^{\text {st }}$ Year & 0.0 & 1.4 & 2.7 & 3.1 & 4.3 & -- \\
\hline & $2^{\text {nd }}$ Year & 0.0 & 2.3 & 3.1 & 3.0 & 3.4 & -- \\
\hline \multirow{2}{*}{ 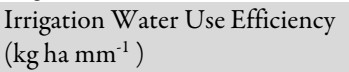 } & $1^{\text {st }}$ Year & 0.0 & 4.8 & 6.2 & 6.1 & 7.5 & -- \\
\hline & $2^{\text {nd }} Y e a r$ & 0.0 & 7.5 & 9.6 & 7.8 & 7.6 & -- \\
\hline
\end{tabular}
the seasonal crop water consumption (mm), and $\mathrm{HI}$ is the harvest index of each treatment. All the experiments were carried out in a randomized complete block design with three replications.

Table 2. Measured lentil crop parameters and obtained statistical results for both the experimental years

Any two numerical values followed by different letters are significantly different from each other at $5 \%$ level of significance. 
240

\section{Dataanalysis}

Analysis of Variance (ANOVA) was performed to test the differences among the main supplementary irrigation treatments. Seasonal irrigation amounts were regressed against each of the variables using the statistical program SPSS (2002). Both, ANOVA and regression tests were considered significant at $\mathrm{p}<0.05$.

\section{Results and Discussion}

As mentioned above, due to higher temperature, higher solar radiation and lower humidity, climatic conditions were more challenging in the first study year. This resulted in a short growth period of the lentil plants in the first year than the second year even after the sufficient irrigation water supply to the fullirrigation treatments.

Depending on the variable supplementary irrigation rates applied to the trial plots, water availability fluctuated the harvest date. In both study years, plants in the $\mathrm{I}_{0}$ and $\mathrm{I}_{25}$ treatments ripened 5-6 days earlier than those in the $\mathrm{I}_{50}$ and $\mathrm{I}_{75}$ treatments and 12-14 days earlier than those in the $\mathrm{I}_{100}$ and $\mathrm{I}_{125}$ treatments. The amount of irrigation applied to the trial plots ranged from 25 to $235 \mathrm{~mm}$ and 25 to $194 \mathrm{~mm}$ in the first year, and second year, respectively as first year was drier than the second study year. Correspondingly, the plant water consumption of the trial plots ranged between $158\left(\mathrm{I}_{0}\right)$ and $330\left(\mathrm{I}_{100}\right) \mathrm{mm}$ in the first year, and $215\left(\mathrm{I}_{0}\right)$ and $360\left(\mathrm{I}_{100}\right) \mathrm{mm}$ in the second year. The lower plant water consumption in the first year of the study was attributed to higher average temperatures that resulted in earlier crop harvest and therefore, decreased the plant water use (Table 2). Erskine and Ashkar (1993) and Subbarao et al. (1995) indicated that lentil can be grown with 250 to $300 \mathrm{~mm}$ precipitation, but depending on the growth stage of the crop, yield loss can be expected due to drought stress. Similarly, Oweis et al. (2004) claimed that lentil yield could be increased by $20-60 \%$ by avoiding water stress.

The lentil plant heights (PHs), depending on the irrigation treatments, varied from 14.3 to $32.0 \mathrm{~cm}$ and from 17.3 to 32.7 $\mathrm{cm}$ in first and second year, respectively. The PHs in the second year were slightly higher than in the first year likely due to the

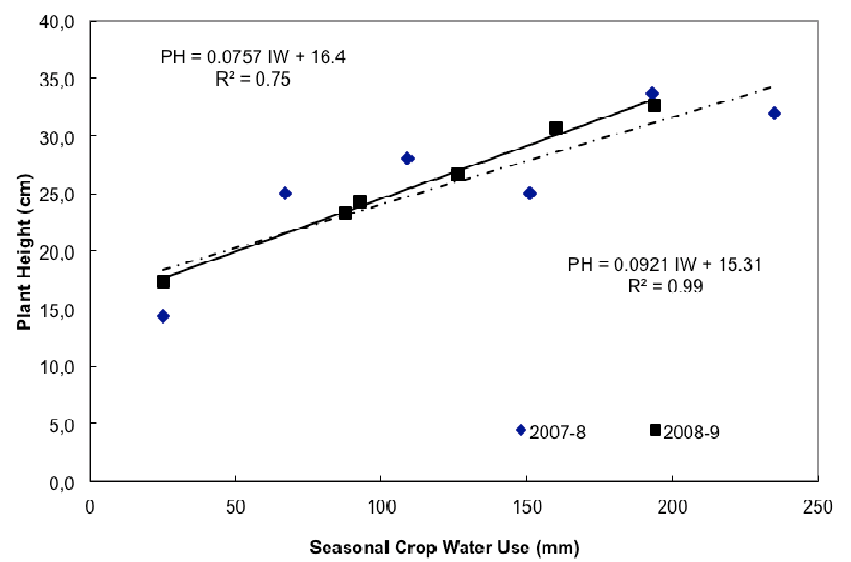

Fig. 1. Relationship between the applied seasonal irrigation water and plant heights obtained for the lentil crop in first and second study year. PH, IW and $\mathrm{R}^{2}$ denote the plant height, irrigation water supply and proportion of variance, respectively different climate conditions. There was no statistically significant difference between the study years, but there was a considerable difference among treatments ( $p>0.05)$. Overall, plant heights increased with the increased irrigation supply. In both study years, there were significant differences between $\mathrm{I}_{0}$ and the other treatments demonstrating the advantage of supplemental irrigation and the effect of drought stress on plant height. When irrigation trials were compared, there were no significant differences among the $\mathrm{I}_{25}, \mathrm{I}_{50}$ and $\mathrm{I}_{75}$ treatments (except $\mathrm{I}_{50}$ in the first year). Similarly, there was no difference between the $\mathrm{I}_{100}$ and $\mathrm{I}_{125}$ treatments (Table 2). The fully irrigated and over-irrigated treatments $\left(\mathrm{I}_{100}\right.$ and $\left.\mathrm{I}_{125}\right)$ produced the tallest $(\mathrm{p}<0.05)$ plants compared to the other treatments, possibly due to the available soil water content and longer growth period. Khourgami et al. (2012) conducted a study to determine the effect of supplementary irrigation on lentil yield components and found that supplementary irrigation significantly increased the lentil plant height that is consistent with our study results. Regression analyses of the plant height showed a significant positive linear relationship between plant height and irrigation with high $\mathrm{R}^{2}$ values ( 0.75 for the first year and 0.99 for the second year), where an additional $1 \mathrm{~mm}$ of irrigation water supply resulted in a 0.9 $\mathrm{mm}$ increase in the plant height in both study years. The linear equations for the 2008 and 2009 data were $P H=0.0757 \mathrm{IW}+$ 16.48 and $P H=0.0921 I W+15.31$, respectively (Fig. 1).

The number of branches per plant $(\mathrm{NB})$ varied from 3.0 to 7.0 and 3.7 to 8.0 in the first year and second year, respectively. In the first year, the $\mathrm{I}_{0}$ trial had significantly $(\mathrm{p}<0.05)$ lower $\mathrm{NB}$, but there were no differences among the other trials. The highest NB average occurred in the $\mathrm{I}_{100}$ trial. Similarly, the lowest $\mathrm{NB}$ average was in the $\mathrm{I}_{0}$ treatment and was significantly lower than the other treatments. The highest NB, on the other hand, was from the $\mathrm{I}_{100}$ trial and was significantly higher than the other trials, except $\mathrm{I}_{125}$. Panahyan-e Kivi et al. (2009) showed that an increase in the number of branches per plant is correlated with the increased irrigation amount. On the contrary, Khourgami et al. (2012) claimed that supplementary irrigation does not have a significant effect on the number of branches per plant in lentils.

A regression analysis of the current data indicated a linear relationship between irrigation water (IW) and the number of

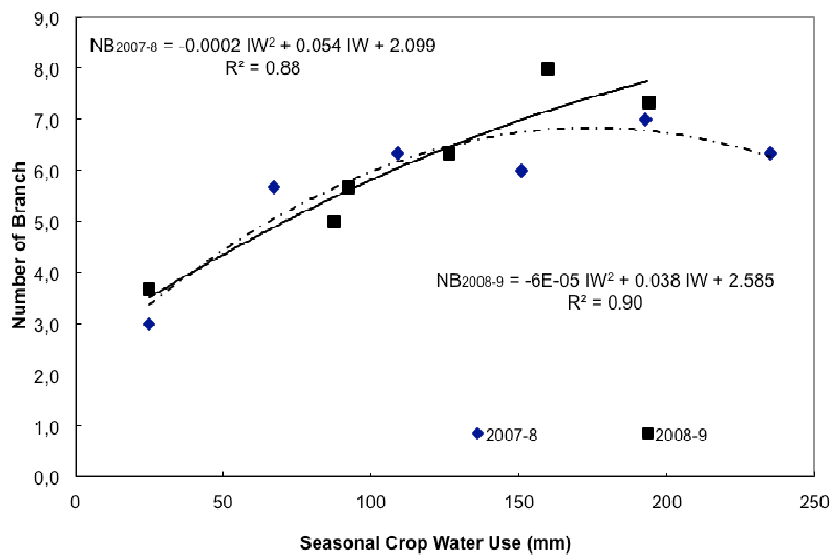

Fig. 2. Relationship between the applied seasonal irrigation water and the number of branch per plant obtained for the lentil crop in first and second study year. NB, IW and $\mathrm{R}^{2}$ denote the number of branches per plant, irrigation water supply and proportion of variance, respectively 


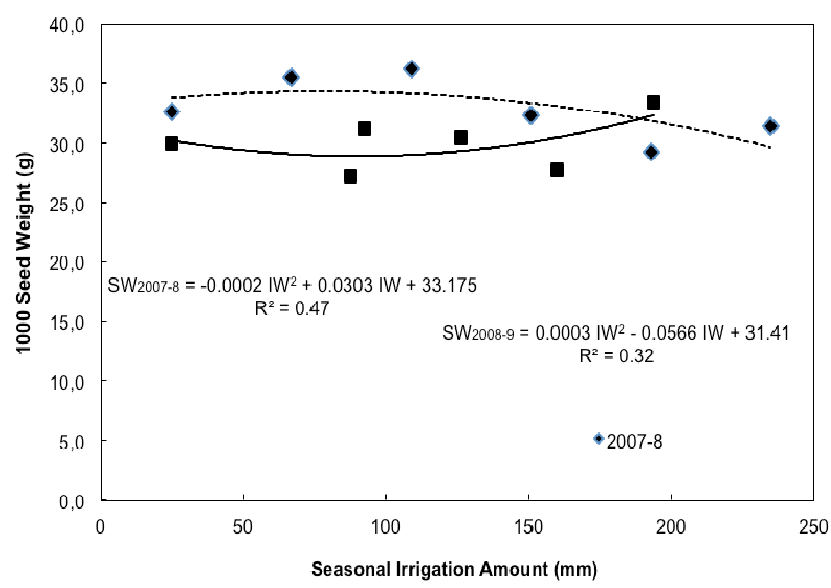

Fig. 3. Relationship between the applied seasonal irrigation water and 1000-seeds weight obtained for the lentil crop in first and second study year. SW, IW and $\mathrm{R}^{2}$ denote the 1000 seeds weight, irrigation water supply and proportion of variance, respectively

lentil plant branches for both study years. The equations were $N B_{2008}=-0.0002 I W^{2}+0.054 I W+2.099\left(R^{2}=0.88\right)$ and $N B_{2009}=-6 E-05 I W^{2}+0.038 I W+2.585\left(R^{2}=0.90\right)$ (Fig. 2).

The lowest 1000-seed weights (SW) from the first and second year crop growing seasons were $29.2\left(\mathrm{I}_{100}\right)$ and $27.2 \mathrm{~g}\left(\mathrm{I}_{25}\right)$, while the highest were $36.2\left(\mathrm{I}_{50}\right)$ and $33.5\left(\mathrm{I}_{125}\right)$ (Table 2), respectively. There was no significant difference among all the trials in both years indicating that irrigation rates do not contribute to seed weights. The regression equations for the 1000 -seed weight of the first and second growing seasons as a function of irrigation water were calculated as $S W_{2008}=-0.0002$ $I W^{2}+0.0303 I W+33.175\left(R^{2}=0.47\right)$ and $S W_{2009}=0.0003$ $I W^{2}-0.0566 I W+31.41\left(R^{2}=0.32\right)$ (Fig. 3).

In both study years, the lowest and highest biomass (BM) values were from non-irrigated $\left(\mathrm{I}_{0}\right)$ and fully irrigated treatments $\left(I_{100}\right)\left(2611\right.$ and $5583 \mathrm{~kg} \mathrm{ha}^{-1}$ in the first year and 3481 and 6912

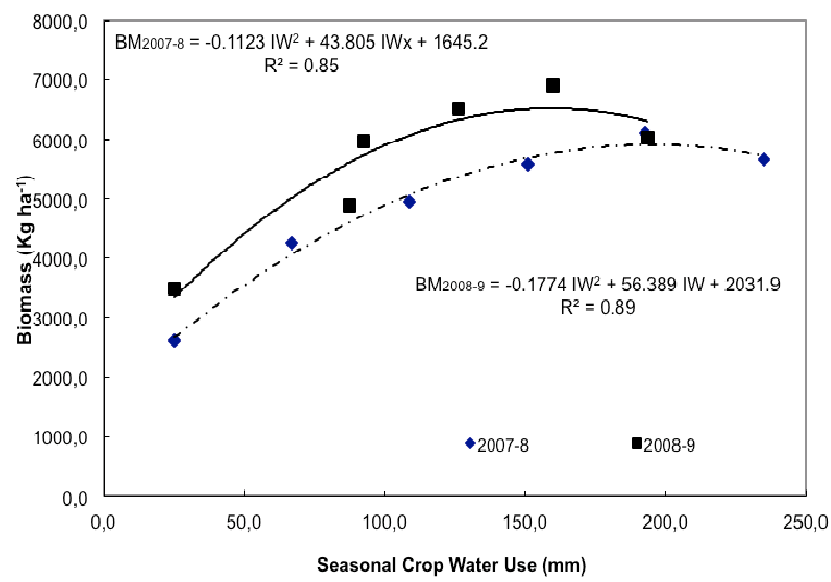

Fig. 4. Relationship between the applied seasonal irrigation water and above ground biomass obtained for the lentil crop in first and second study year. BM, IW and $\mathrm{R}^{2}$ denote the above ground biomass, irrigation water supply and proportion of variance, respectively $\mathrm{kg} \mathrm{ha}^{-1}$ in the second year). The difference in the BM values between the study years can be attributed to climatic conditions that led to an earlier harvest resulting in the low BM in the first study year. Analysis of the data indicated that the BM in both study years significantly increased with increased irrigation amounts, resulting in maximum $\mathrm{BM}$ under full-irrigation treatments. Similar to our results, Hosseini et al. (2011) reported that lentil BM values from irrigated plots were higher when compared to the non-irrigated plots. The relationship between irrigation treatments and biomass was linear and statistically significant $(\mathrm{p}<0.05)$. The equations for both years were $B M_{2008}=$ $-0.1123 I W^{2}+43.805 I W x+1645.2\left(R^{2}=0.85\right)$ and $B M_{2009}=-$ $0.1774 I W^{2}+56.389 I W+2031.9\left(R^{2}=0.89\right)$, with both of the equations being significant $(\mathrm{P}<0.05)$.

In both trial seasons, the lowest yield $(\mathrm{Y})$, as anticipated, was from the $\mathrm{I}_{0}$ (dry land conditions) trials $\left(291 \mathrm{~kg} \mathrm{ha}^{-1}\right.$ in the first year and $577 \mathrm{~kg} \mathrm{ha}^{-1}$ in the second year), while the highest yields were from the $I_{100}$ treatment $\left(1536 \mathrm{~kg} \mathrm{ha}^{-1}\right.$ in the first year and $1788 \mathrm{~kg} \mathrm{ha}^{-1}$ in the second year). Several researchers have determined similar effects of supplementary irrigation on lentil yield. Lal et al. (1988) claimed that drought during the filling stage of lentil reduces both the number of pods per plant and the number of seeds per pod resulted in reduced yield. Erskine and Ashkar (1993) and Hudak and Patterson (1995) claimed that irrigation during the lentil grain filling stage increases the yield. Bhattacharya (2009), Hosseini et al. (2011) and Khourgami et al. (2012) also indicated that the supplementary irrigation had positive effect on lentil yield. Sarker $e t$ al. (2003) indicated that irrigation during the reproductive stage increases the lentil yield. In current study, the low yield values obtained from the $\mathrm{I}_{0}$ (dryland) trial highlighted the necessity and importance of supplemental irrigation under semi-arid climatic conditions. Statistical analysis of the yield data indicated the differences in both, among the study years and among the irrigation treatments $(p<0.05)$ (Table 2). Since there was no statistical difference in 1000 seed weights among all trials, it is confirmed that yield difference was due to number of seeds per plant. This clearly pointed out that supplement irrigation statistically increases the number of seeds per plant as observed in our yield data.

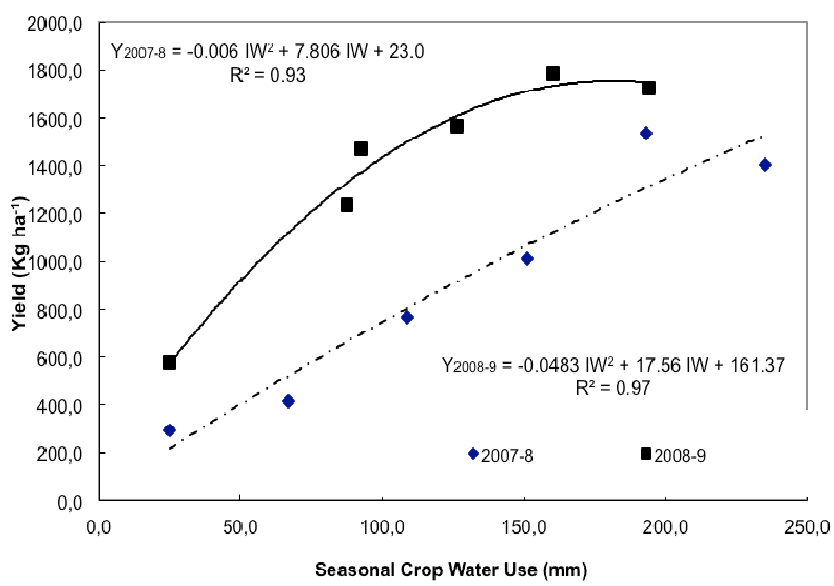

Fig. 5. Relationship between the applied seasonal irrigation water and crop yield obtained for the lentil crop in first and second study year. Y, IW and R2 denote the yield, irrigation water supply and proportion of variance, respectively 
242

In the first experimental year, the yield values were consistently lower than the second year likely due to shorter harvest time. Panahyan-e Kivi et al. (2009) conducted an experiment using different irrigation rates and lentil cultivars and reported a minimum yield of $869 \mathrm{~kg} \mathrm{ha}^{-1}$ and a maximum yield of $1340 \mathrm{~kg} \mathrm{ha}^{-1}$. While the yield from the non-irrigated plants in their study was higher than our study possibly due of higher precipitation, the other yields were similar to our results. Irrigation amounts were regressed with yield values using a linear model, and high coefficient of determination $\left(\mathrm{R}^{2}\right)$ values were obtained for both study years.

Regression equations for 2008 and 2009 were $Y_{2008}=-0.006$ $I W^{2}+7.806 I W+23.0\left(R^{2}=0.93\right)$ and $Y_{2009}=0.0483 I^{2}+$ $17.56 I W+161.37\left(R^{2}=0.97\right)$, both of which were statistically significant $(\mathrm{P}<0.05)$ (Fig. 4).

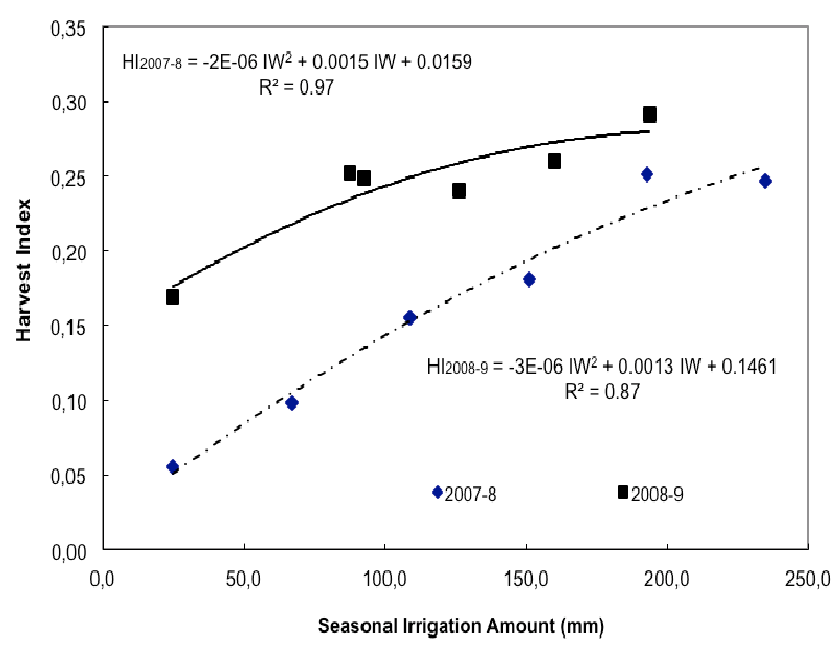

Fig. 6. Relationship between the applied seasonal irrigation water and harvest index obtained for the lentil crop in first and second study year. HI, IW and $\mathrm{R}^{2}$ denote the harvest index, irrigation water supply and proportion of variance, respectively

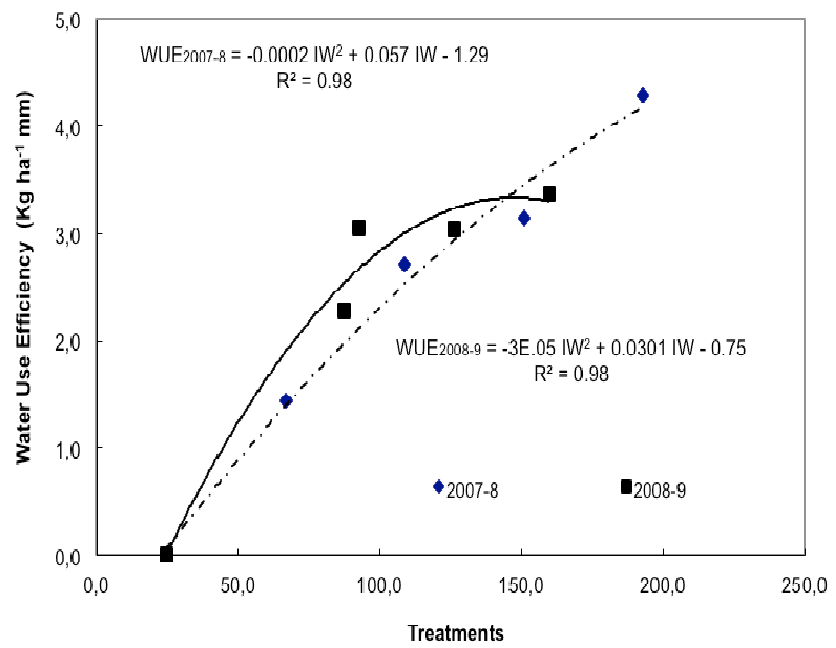

Fig. 7. Relationship between the applied seasonal irrigation water and water use efficiency obtained for the lentil crop in first and second study year. WUE, IW and $\mathrm{R}^{2}$ denote the water use efficiency, irrigation water supply and proportion of variance, respectively

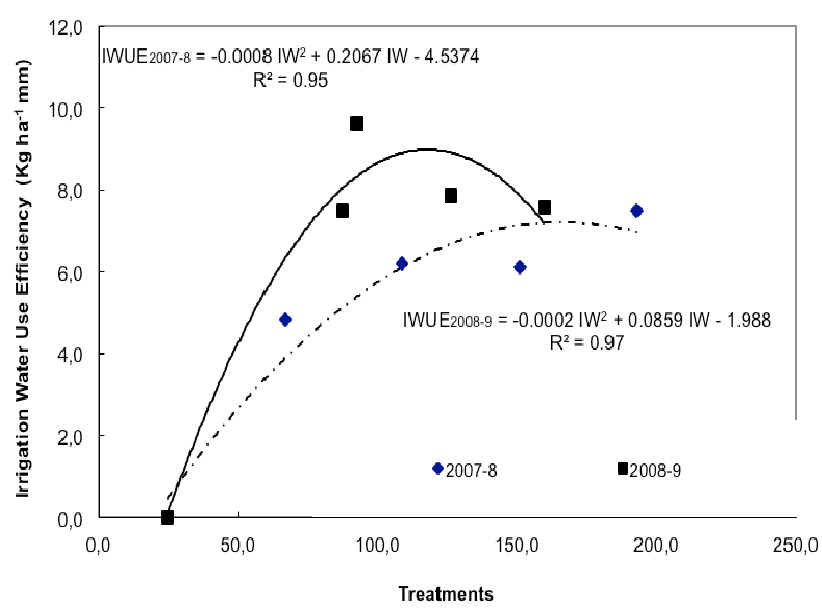

Fig. 8. Relationship between the applied seasonal irrigation water and irrigation water use efficiency obtained for the lentil crop in first and second study year. IUWE, IW and $\mathrm{R}^{2}$ denote the irrigation water use efficiency, irrigation water supply and proportion of variance, respectively

In the first year, the lowest, 0.06 , and the highest, 0.25 , harvest index values were obtained from the $\mathrm{I}_{0}$ and $\mathrm{I}_{100}$ treatments, respectively. ANOVA test results did not indicate any significant differences between $\mathrm{I}_{0}$ and $\mathrm{I}_{25}$, between $\mathrm{I}_{50}$ and $\mathrm{I}_{75}$ and between $\mathrm{I}_{100}$ and $\mathrm{I}_{125}$. On the other hand, in the second experiment year, even though irrigation seems to improve the harvest index, there was no significant $(\mathrm{P}<0.05)$ difference among all the trials, except $\mathrm{I}_{0}$ (Table 2).

Based on our results, it seems that supplementary irrigation improves the harvest index. Panahyan-e Kivi et al. (2009) reported the harvest index values ranging from 0.22 to 0.30 that were similar to the present study results. Regression analysis of the harvest index values against the total irrigation amounts indicated a positive polynomial equation for both the seasons. The statistically significant $(\mathrm{p}<0.05)(\mathrm{Fig} .5)$ regression equation of the combined harvest index data was $H I=-2 \mathrm{E}-06 \mathrm{IW}^{2}+$ $0.0018 I W+0.033$ with $R^{2}$ value of 0.92 (Fig. 6).

Water use efficiencies (WUE) in the first and second year varied from $1.4\left(\mathrm{I}_{25}\right)$ to $4.3\left(\mathrm{I}_{100}\right)$ and from 2.3 to 3.4 , respectively. WUE values in the first year of the study were higher than the second year, and that difference was attributed to the drier climate conditions. As expected with increased irrigation amounts, the WUE also increased. Gholipoor and Soltani (2008) reported WUE values similar to the current study, and their values ranged from 3.5 to 5.2 depending on the location of the trials in Iran. Regression analysis of the WUE data indicated a significant relationship between the crop ET and WUE, and the equation was $W U E_{2008}=-0.0002 E T^{2}+0.057 E T-1.29$ and $W U E_{2009}=-3 \mathrm{E} .05 E T^{2}+0.0301 E T-0.75$, both equations having $R^{2}=0.98$ (Fig. 7).

In present study, irrigation water use efficiencies (IWUE) ranged from 1.4 to $4.3 \mathrm{~kg} \mathrm{ha}^{-1} \mathrm{~mm}^{-1}$ and from 2.3 to $3.4 \mathrm{~kg} \mathrm{ha}^{-1}$ $\mathrm{mm}^{-1}$ for the first and second year, respectively. Overall, an increase in the yield resulted in significantly $(p<0.05)$ increased IWUE. Regression analysis of the data indicated significant relationships for IWUE of both of the years, and the equations were $I W U E_{2008}=-0.0008 I W^{2}+0.2067 I W-4.5374\left(R^{2}=\right.$ $0.95)$ and $I W U E_{2009}=-0.0002 I W^{2}+0.0859 I W-1.988\left(R^{2}=\right.$ 0.97 ) for 2008 and 2009, respectively (Fig. 8). 


\section{Conclusions}

Lentil is one of the most significant pulse crops that can be a high protein source to the people unable to afford animal protein. As it is traditionally grown as a rain-fed crop, its production is highly influenced by rise in global temperature, diminished precipitation and persistent drought stress. In such situation, application of technologies like supplemental irrigation may serve as a viable option to improve crop productivity. Hence, in this study the effect of supplemental irrigation on lentil yield and its components under the semi-arid climate conditions of the Harran plain, Sanliurfa, Turkey was studied. Based on the study results, $400-450 \mathrm{~mm}$ of total moisture (including rainfall and supplementary irrigation) has been recommended for the optimum lentil growth and yield under similar climatic conditions. Moreover, on one hand, where appropriate supplementary irrigation improved the lentil yield, on other side, over-irrigation (more than full irrigation) lowered the measured parameters including yield. So, we can conclude that the farmers need to precisely understand the supplementary irrigation technology before employing it. Although the technique has emerged as a doable way to improve productivity, it must be properly organized with other soil management practices and efficient germplasm to obtain the preferred outcome. Additionally, under similar growth conditions and under no water stress, $6000-7000 \mathrm{~kg}$ $\mathrm{ha}^{-1}$ of above ground biomass and $1500-1800 \mathrm{~kg} \mathrm{ha}^{-1}$ lentil yield could be expected. Moreover, methods used for supplementary irrigation should be cost-effective, automated, easily movable from one farm to another and efficient to make scheduled irrigations to fulfil the crop prerequisites at specific growth stages. Results obtained in the study would facilitate the farm irrigation practices especially in the semi-arid climatic conditions that consequently may improve the lentil production.

\section{References}

Abi-Ghanem R, Carpenter-Boggs L, Smith JL (2011). Cultivar effects on nitrogen fixation in peas and lentils. Biology and Fertility of Soils 47 (1):115-120.

Ali A, Shuang-En Y, Panda S, Guang-Cheng S (2015). Water harvesting techniques and supplemental irrigation impact on sorghum production. Journal of the Science of Food and Agriculture 95(15):3107-3116.

Attia M, Barsoum M (2013). Effect of supplementary irrigation and biofertilization on wheat yield productivity under rainfed conditions. Alexandria Journal of Agricultural Research 58(2):149-157.

Baker JM, Griffis TJ, Ochsner TE (2012). Coupling landscape water storage and supplemental irrigation to increase productivity and improve environmental stewardship in the US Midwest. Water Resources Research 48(5).

Bhattacharya A (2009). Yield determination in lentil under non-irrigated and irrigated conditions: phenology, dry matter distribution and yield attributes. Indian Journal of Agricultural Research 43(1):1-9.

Dogan E, Kahraman A, Bucak B, Kirnak H, Guldur M (2013). Varying irrigation rates effect on yield and yield components of chickpea. Irrigation Science 31(5):903-909.
Doorenbos J, Kassam A (1979). Yield Response to Water. FAO Irrigation and Drainage Paper No33, Rome, Italy.

Erekul O, Klaus-Peter G, Gürbüz T (2012). Effect of supplemental irrigation on yield and bread-making quality of wheat (Triticum aestivum L.) varieties under the Mediterranean climatical conditions. Turkish Journal of Field Crops 17(1):78-86.

Erskine W, El Ashkar F (1993). Rainfall and temperature effects on lentil (Lens culinaris) seed yield in Mediterranean environments. The Journal of Agricultural Science 121(3):347-354.

FAOSTAT (2015).http://faostat3.fao.org

Gholipoor M, Soltani A (2008). Assessing potential drought avoidance for five crops in Iran using long-term weather data. International Journal of Agricultural Research 3(3):202-210.

Girma F, Haile D (2014). Effects of supplemental irrigation on physiological parameters and yield of faba bean (Vicia faba L.) varieties in the Highlands of Bale, Ethiopia. Journal of Agronomy 13(1):29.

Hamdi A, Erskine W, Gates P (1992). Adaption of lentil seed yield to varying moisture supply. CropScience 32(4):987-990.

Hosseini F, Nezami A, Parsa M, Hajmohammadnia GK (2011). Effects of supplementary irrigation on yield and yield components of lentil (Lens culinaris Medik.) cultivars in Mashhad climate. Journal of Water and Soil (Agricultural Sciences and Technology) 25(3):625-633.

Hudak C, Patterson RP (1995). Vegetative growth analysis of a droughtresistant soybean plant introduction. CropScience 35(2):464471.

Kanber R (1999) Sulama. CU Ziraat Fakultesi Genel Yayin no. 174, Ders Kitaplari Yayin NoA-52.

Khourgami A, Maghooli E, Rafiee M, Bitarafan Z (2012). Lentil response to supplementary irrigation and plant density under dry farming condition. International Journal of Science and Advanced Technology 2(2):51-55.

Lal M, Gupta P, Pandey R (1988). Response of lentil to different irrigation schedules (Lensculinaris).LENSNewsletter(ICARDA).

Lardy G, Anderson V (2009). Alternative feeds for ruminants. General concepts and recommendations for using alternative feeds. North Dakota StateUniversity Fargo, AS-1182 (Revised) 24p.

Oweis T, Hachum A (2001). Reducing peak supplemental irrigation demand by extending sowing dates. Agricultural Water Management 50(2):109123.

Oweis T, Hachum A, Pala M (2004). Lentil production under supplemental irrigation in a Mediterranean environment. Agricultural Water Management68(3):251-265.

Oweis T, Hachum A (2003). Improving water productivity in the dry areas of West Asia and North Africa. In: Kijne WJ, Barker R, Molden D (Eds). Water Productivity in Agriculture: Limits and Opportunities for Improvement. CABIPublishing, Wallingford, UKpp 179-198.

Oweis T, Hachum A (2012). Supplemental irrigation, a highly efficient waterusepractice.ICARDA, Aleppo,Syria.

Pala M, Mazid A (1992). On-farm assessment of improved crop production practices in Northwest Syria. II. Lentil. Experimental Agriculture 28(2):185-193.

Panahyan-e-Kivi M, Ebadi A, Tobeh A, Jamaati-e-Somarin S (2009). Evaluation of yield and yield components of lentil genotypes under drought stress. Research Journal of Environmental Sciences 3(4):456460. 
244

Pandey PK, van der Zaag P, Soupir ML, Singh VP(2013). ANew Model for SimulatingSupplemental Irrigation and the Hydro-Economic Potential of a Rainwater Harvesting System in Humid Subtropical Climates. Water Resources Management 27(8):3145-3164.

Sarker A, Kumar S (2011). Lentils in production and food systems in West Asia and Africa. Grain Legumes 57:46-48.

Sarker A, Erskine W, Singh M (2003). Regression models for lentil seed and straw yields in Near East. Agricultural and Forest Meteorology 116:6172.

Saxena M (1981). Agronomy of lentils. Lentils. Common Wealth Agricultural Bureaux, Norwich: 111-129.

Serttas S (2009). Turkey Grain and Feed July Lock Up Report. USDA Gain report TU9025.

Shamsi K, Kobraee S, Haghparast R(2010). Drought stress mitigation using supplemental irrigation in rainfed chickpea (Cicer arietinum $\mathrm{L}$.) varieties in Kermanshah, Iran. African Journal of Biotechnology 9(27):41974203.

Silim S, Saxena M, Erskine W (1993). Adaptation of lentil to the Mediterranean environment. I. Factors affecting yield under drought conditions. Experimental Agriculture 29(1):9-19.

Singh R, Kundu D, Bandyopadhyay K (2010). Enhancing agricultural productivity through enhanced water use efficiency. Journal of Agricultural Physics 10:1-15.
Soltani M, Liaghat AM, Sotoodehnia A, Heidari A, Kamali B (2015). Conjunctive effects of supplemental irrigation and planting date on rainfed lentil in Qazvin Plain, Iran. Journal of Irrigation and Drainage Engineering 141(12):05015005.

SPSS (2002). SPSS 11.5 for Windows Update, SPSS Inc, Chicago, Illinois, USA.

Subbarao G, Johansen C, Slinkard A, Nageswara Rao R, Saxena N, Chauhan Y, Lawn R (1995). Strategies for improving drought resistance in grain legumes. Critical Reviews in Plant Sciences 14(6):469-523.

Sui R, Byler RK, Fisher DK, Barnes EM, Delhom CD (2014). Effect of supplemental irrigation and graded levels of nitrogen on cotton yield and quality. Journal of Agricultural Science 6(2):119.

USSL (1954). Diagnosis and improvement of salinity and alkaline soil. USDA Hand Book no. 60, Washington.

Zhang H, Pala M, Oweis T, Harris H (2000). Water use and water-use efficiency of chickpea and lentil in a Mediterranean environment. Crop and Pasture Science 51(2):295-304. 